\title{
Gender and climate change-induced conflict in pastoral communities: Case study of Turkana in north- western Kenya
}

\author{
Nancy A. Omolo*
}

\begin{abstract}
Clitmate change-induced conflict is a major global threat to human security and the environment. It has been projected that there is going to be an increase in climate changes resulting in increased droughts and floods in northern Kenya. Climate change impacts will be differently distributed among different regions, ages, income groups, occupations and gender. People living in poverty are more vulnerable to environmental changes. In relation to these concerns, this article discusses the following issues: climate change, pastoralism and conflicts, gender issues in Turkana, and the future of pastoralism in relation to changing climate conditions. Specifically, the first section looks at the impacts of climate change on pastoralism and the livelihoods of pastoralists, and at the types of climate change-induced conflicts in Turkana. The next section focuses on the impact of climate change-induced conflict on women and men's livelihoods, including discussion of the roles and participation in decision making. Finally, the future of pastoralism in relation to changing climate is discussed. The focus will be on scenarios of the past and future projections of rainfall patterns in Turkana,
\end{abstract}

* Nancy A. Omolo is a climate change consultant in Kenya and a Ph.D. candidate at the University of KwaZulu-Natal, Durban. 


\section{Nancy A. Omolo}

the future of pastoralism and the possibility of climate-induced conflicts in the future.

\section{Introduction}

Turkana is situated in north-western Kenya. Turkana was initially one district but it was divided into three districts in 2007, forming Turkana Central district, Turkana North district and Turkana South district. The districts form part of the 43 districts in the Rift Valley Province (GoK 2008:19). Turkana covers a total area of $77000 \mathrm{~km}^{2}$. The population size in the year 2002 was 497779 (GoK 2002:8). Turkana's temperature ranges between 24 and $38^{\circ} \mathrm{C}$, and the mean temperature is $30^{\circ} \mathrm{C}$. The driest months are January, February and September. The districts experience longer rains (which are usually erratic and unreliable, however) between April and July, while short rains are experienced between October and November. The rainfall ranges between 300 and $400 \mathrm{~mm}$ per annum, with the lowest rainfall being $120 \mathrm{~mm}$. According to the Welfare Monitoring Survey (WMS 1994, cited in GoK 2002:4 and 8), the overall poverty in Turkana was $74 \%$ and food poverty $81 \%$. Turkana Central, Turkana North and Turkana South are some of the poorest districts in Kenya. The overall poverty, also known as absolute poverty, in Kenya was 46\% in 2005 (GoK 2005a:13).

Turkana is already experiencing problems related to climate variability and change, mainly droughts and floods. Climate is generally described in terms of the mean and variability of temperature, precipitation and wind over a period of time, ranging from months to millions of years - the classical period being 30 years (Le Treut 2007:96). According to Hegerl et al. (2007:667), climate change refers to a shift in the mean state of climate or its variability persisting for an extended period of time (decades or longer), which might be due to natural changes or persistent anthropogenic changes in the composition of the atmosphere or in land use. While climate variability refers to variation in the mean state of climate on a temporal and spatial scale beyond that of individual weather events, examples of climate variability include extended droughts, floods and conditions that result from periodic El Niño and El Niña events (Hegerl et al. 2007:667). However, despite the marked progress made in recent 


\section{Gender and climate change-induced conflict in pastoral communities}

years, particularly with model assessments, the climate in many parts of Africa is still not fully understood (Boko et al. 2007:458).

In relation to climate variability and change, resource competition amongst pastoralist groups of land users significantly increases the risk of conflict. The risk is greatest during times of stress (for example, during droughts or floods), when available resources are even more restricted. According to Barnett and Adger (2007:641), environmental change - in isolation from a broader range of social factors - has not undermined human security. These may include poverty, the degree of support (or discrimination) communities receive from the state, their access to economic opportunities, the effectiveness of decision-making processes, and the extent of social cohesion within and surrounding vulnerable groups. All these factors determine people's and communities' entitlements to economic and social capital that in turn determine their capacity to adapt to climate change so that the things that they value are not adversely affected. This article looks at the specific type of conflict in Turkana: livestock raiding and the way in which it has been transformed over the years, from a cultural practice (redistributive raiding) into a more predatory activity/commercial activity.

It has been predicted that climate change will accentuate the gaps between the world's rich and poor. In the developing world, it is an accepted view that women are amongst the poorest and most disadvantaged groups in society and 70\% of the 1,3 billion people in the developing world living below the poverty threshold are women (Denton 2001:1). In many societies vulnerability differs between women and men. Women are vulnerable to environmental changes because of their responsibilities in the family, which are exacerbated by the impacts of climate change. Since access to basic needs and natural resources, such as food, water and fuel, becomes hampered, women's workload has increased (Dankelman et al. 2008:10).

This article is based on a study entitled 'Enhancing adaptive capacity of pastoralists to climate change induced vulnerability in northern Kenya'. The first phase of the project started in January 2008 and ended in December 2009. The study was carried out by the Kenya Vulnerability Research Team (KVRT), comprised 


\section{Nancy A. Omolo}

of five institutions, namely: Practical Action, Foodlink Resources, National Environmental Management Authority (NEMA), University of Maseno and Kenyatta University. The project was funded by the International Development Research Centre (IDRC) and the UK Department for International Development (DFID).

Turkana was selected for the study on the basis that it has been subjected to historical and recurrent droughts that have left the region vulnerable. The area is in Arid and Semi Arid Lands (ASALs) where managing short-term climatic fluctuations as well as adapting to long-term changes is critical to sustaining livelihoods. Furthermore, the districts experience structural challenges characteristic of low levels of development, that is, high poverty levels, high illiteracy levels and continuous food insecurity.

The selection of the study sites in Turkana was based on variability of socioeconomic activities/types of livelihoods (that is, pure/primary pastoralists and agro-pastoralists), the distance of case study areas from each other (to provide ecological and livelihood differences), existence/non-existence of outside interventions to reduce community vulnerability to droughts/floods (for example, the Arid Lands Resource Management Project [ALRMP] which is being implemented by the Government of Kenya with the support of the World Bank and non-governmental organisations [NGOs]) because these interventions have an influence on community level vulnerability, and security/access of the study site (this is because of frequent inter-ethnic and cross-border conflicts related to access to natural resources like water and pasture). The study sites were Kapua (pure/primary pastoralists) in Turkana North district, Katilu (agro-pastoralists) in Turkana South district and Namoruputh (pure/primary pastoralists but with various interventions by NGOs) in Turkana Central district.

Stratified random sampling was adopted for this study. The determination of the sample size was based on the demographic data and the clustering of households in the settlement areas using statistics from the ALRMP in Turkana. These were found to be more reliable as compared with the information from the public administration officers (Chiefs) which was normally inflated in the expectation 


\section{Gender and climate change-induced conflict in pastoral communities}

of relief food. The unit of analysis was the individual household, with every third household being selected for data collection. The target respondents of the closed/structured survey questionnaires were based on gender (either a woman or a man household head) in an alternating way. The total populations of the study sites were as follows: Namoruputh - 2 075; Katilu - 5509 and Kapua - 5 458. The numbers of households in the three study areas were: Namoruputh - 346, Katilu - 918 and Kapua - 910 (altogether 2 174). To enhance statistical accuracy during data analysis, $30 \%$ of the households were sampled, giving the following sample sizes: Namoruputh - 104 households; Katilu - 275 households and Kapua - 273 households. These figures were proportionately divided among the villages. Therefore a total of 652 questionnaires were administered at the household level. To complement closed survey questionnaires, Focused Group Discussions (FGDs) were also carried out using open-ended survey questionnaires. The process involved having women only and men only FGDs. A total of 6 FGDs were carried out, 2 at each site, focusing on women and men household heads in the specified study sites. Meteorological data involved the acquisition and analysis of temperature and precipitation patterns from 1960 to 2009, while climate modelling entailed developing climate scenarios of temperature and rainfall for the period of 2020-2040, using the Providing Regional Climates for Impacts Studies (PRECIS) package. The results derived from the model included seasonal variability and annual variability of temperature and precipitation, and mapping out the scenarios.

\section{Climate change, pastoralism and conflicts}

\section{Climate variability and change}

The impacts of climate change are likely to be spatially variable, and developing countries - many in Africa - generally are considered more vulnerable than developed countries due to their lower capacity to adapt (Thomas and Twyman 2005:115-116). Climate variability and change will result in fundamental alterations to ecosystem structures and functions. These in turn will affect human land-use and livelihoods and have the potential to make pastoralists 


\section{Nancy A. Omolo}

more vulnerable (Galvin et al. 2004:1). In the future, climate change may become a contributing factor to conflicts, particularly those concerning resource scarcity (Ashton 2002; Fiki and Lee 2004, cited in Boko et al. 2007:443). The KVRT preliminary findings (KVRT 2009) reveal the factors that have contributed to changes in vegetation over the years (which included droughts and floods) in Turkana.

\section{Pastoralism}

The Turkana who are seriously affected by inter-ethnic and cross-border conflicts over natural resources are mainly pastoralists. Pastoralism is a lifestyle most adapted to the harsh environments of ASALs. It involves moving animals, exchanging animals and sometimes selling animals to deal with cyclical droughts. The dry and pastoral lands occupy more than $80 \%$ of Kenya, and are home to approximately 4 million pastoralists who constitute more than 10\% of Kenya's population (Kirbride and Grahn 2008:8). Livestock is their major source of livelihood and food security. Kenya's livestock production accounts for $24 \%$ of total agricultural output. Over $70 \%$ of the country's livestock and $75 \%$ of the wildlife are in the ASALs (GoK 2005b, cited in Orindi et al. 2007:1). The Turkana district borders Ethiopia, Sudan and Uganda as shown in Figure 1 below. Within Kenya, the Turkana district borders West Pokot district, Baringo district, Samburu district and Marsabit district (GoK 2002:4). 
Figure 1: Map of Turkana district (Cullis and Pacey 1992:186)

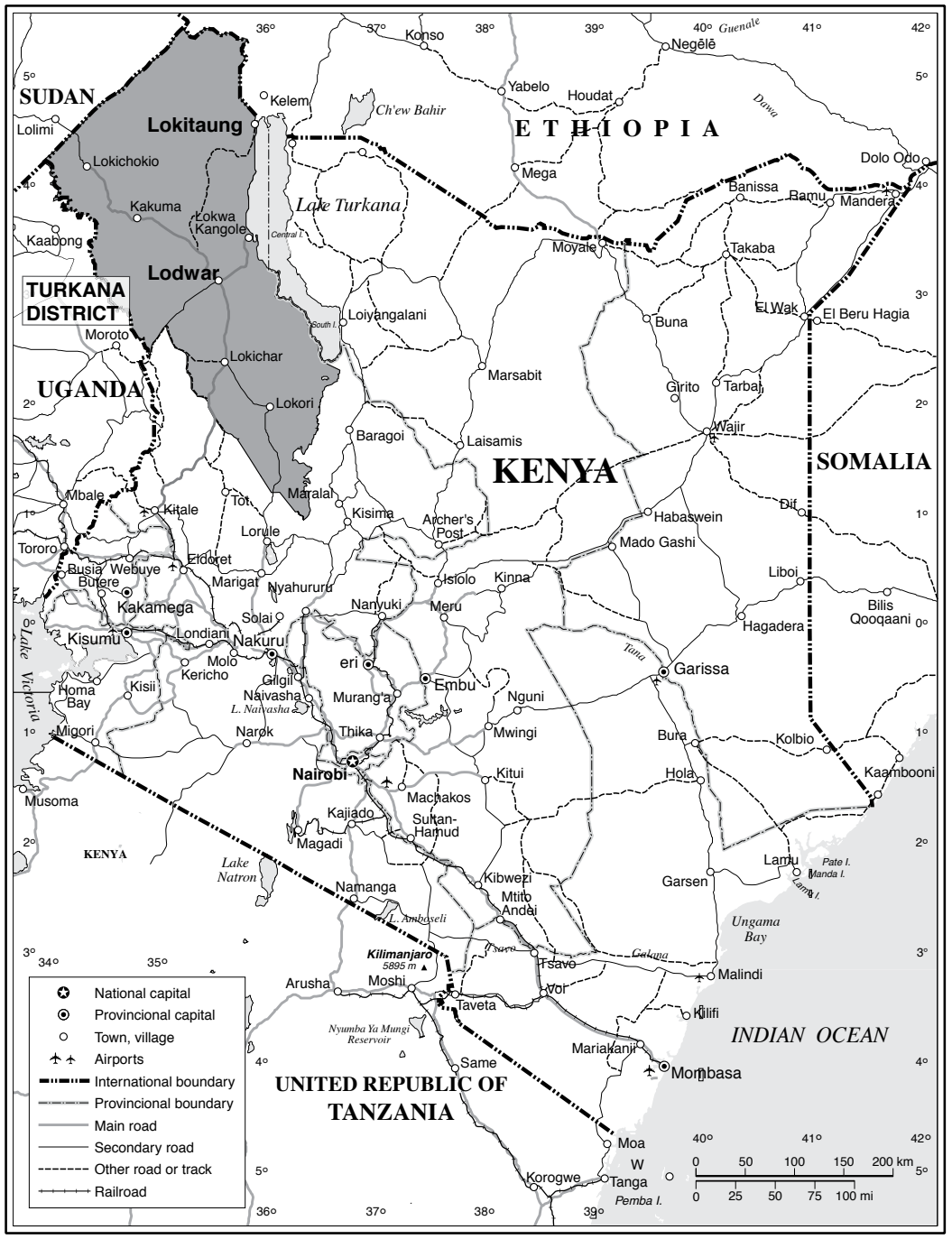




\section{Nancy A. Omolo}

\section{Climate change-induced conflict}

The Turkana, like their neighbours, have a livestock raiding culture. Raiding of traditional enemies was previously a means of expanding grazing lands, gaining access to new water sources and most importantly, an economic stratagem of self-restocking and improving social status by acquiring livestock from defeated enemies (Oba 1992:7). This means that each raid is spontaneously followed by counter raids. According to Watson (2003:7), other motivation for raids in pastoral communities is the desire to reduce poverty and hunger, and acquire bridewealth.

The challenging problem is the way in which livestock raiding has been transformed over the years, from a cultural practice/redistributive raiding into a more predatory activity/commercial activity. Watson (2003:9) states that in 'commercial' raiding the promoters may not necessarily be pastoralists themselves, but may also include ex-pastoralists. In Turkana, the increase in 'commercial' raiding includes cases of 'sponsored' raiding where guns are provided to young men by wealthy people who wish to acquire livestock for sale. This has been facilitated by the general economic stagnation in the Horn of Africa which has contributed to the development of informal 'parallel' economies. These markets are unconstrained by national frontiers and are largely controlled by people in positions of political power or with access to weapons (Hendrickson et al. 1998:186). The outcome, due to the use of modern weapons in raids, has been more destructive and has led to lasting hostilities among the Turkana and their neighbouring tribes: the Toposa (Sudan), the Karamojong (Uganda), the Donyiro (Ethiopia), the Merille (Ethiopia) and the Pokot (Kenya).

According to Kirbride and Grahn (2008:21), resource competition also significantly increases the risk of conflict between different groups of land users. This risk is enhanced during times of stress (that is, during drought or floods). For example, it was reported that renewed clashes between the Turkana in northern Kenya and the Toposa in southern Sudan, both seeking to access grazing land and water in the Nadapal Belt, reportedly left more than 20 people dead and 60000 animals stolen within three months (Daily Nation 2009b). The Nadapal 


\section{Gender and climate change-induced conflict in pastoral communities}

Belt is inhabited by the two groups and is very productive, but peace has remained elusive. International aid agency Oxfam during the launch of a $\$ 9,5$ million appeal to help victims of drought (Nairobi, September 2009), said that drought for the fifth year running is driving more than 23 million east Africans in seven countries towards severe hunger and destitution. Absent and unpredictable rains are more common in the region, wet seasons are becoming shorter and droughts have increased from once a decade to every two or three years (Daily Nation 2009a). KVRT preliminary findings (KVRT 2009) point out that the Turkana migrate due to the following reasons: search for pasture and water $(52,7 \%)$, conflicts (21,9\%), search for larger pieces of land (6\%), and culture (2\%).

Kirbride and Grahn (2008:22) state that community agreements governing access to and the sharing of resources have been developed to prevent recurring conflicts, but these agreements have not been well disseminated. There do exist conflict-mitigating institutions at local and national levels, with officers seconded to them from government, as well as district peace committees. However, their effectiveness in practical early warning of conflicts and rapid response is hampered by a lack of funding and resources from government. Climate change is therefore likely to increase the drivers of conflict leading to pastoralists becoming more vulnerable.

\section{Coping and adaptation strategies}

Due to the impact of climate variability and change, the Turkana are diversifying their livelihoods. This process has been hastened by conflicts, especially livestock raids. Various studies have been undertaken on pastoralists' alternative livelihoods in Turkana (that is, Birch and Grahn 2007:2; Galvin et al. 2004:2; McCabe 1990:87; Oba 1992:1). Impacts of global climate change are not only physical and economic, but also social and cultural, jeopardising environmentally based livelihoods in many areas of the world (Orindi et al. 2007:5-6). Due to the long experience of environmental uncertainty in Turkana, the pastoralists have developed a highly flexible social system and an elaborate set of both individual and collective-based survival strategies. These include: mobility; herd splitting; 


\section{Nancy A. Omolo}

the redistribution of surplus livestock within social networks; diversification of livestock comprised of camels, goats, sheep, cattle and donkeys to enable them to exploit different expanses of the range during any period of the year; livestock loans and gifts; formation of complex social security networks based on kinship and friendship; reliance on relief food, fishing on Lake Turkana, farming along the rivers and gathering wild fruits.

To support the above literature, Table 1 below indicates KVRT preliminary findings (KVRT 2009) on the emerging coping strategies which include: remittances from relatives; praying; joining merry-go-round groups by both women and men; transformation of pastoralists into agro-pastoralists, especially in areas situated next to water sources; seeking employment (mostly casual labour); engaging in businesses, for example, selling firewood and charcoal as well as weaving baskets. Sources of income varied in the three study sites as follows: Katilu is an agro-pastoralist area situated next to river Turkwell, and a key source of income amongst women and men is selling agricultural produce (for women at $37 \%$ and for men at $42 \%$ ). In Kapua, the sources of income from selling livestock/livestock products amongst women and men were at 3,9\% and $21,9 \%$, respectively. Farming is not an alternative livelihood in Kapua because the area is very dry, but another source of income is charcoal burning by both women and men at $37,6 \%$ and $41,1 \%$, respectively. On the other hand in Namoruputh, income from selling livestock products amongst women and men was $36 \%$ and $48,8 \%$, respectively. In Namoruputh women are highly involved in selling of firewood at 20,4\%, while men are more involved in businesses at $14,6 \%$. The KVRT preliminary findings (KVRT 2009) indicate that charcoal burning is more prominent in dry areas with few or no alternative sustainable livelihoods. 
Gender and climate change-induced conflict in pastoral communities

Table 1: Sources of income

\begin{tabular}{|l|c|c|c|c|c|c|}
\hline $\begin{array}{l}\text { SOURCES OF } \\
\text { INCOME }\end{array}$ & \multicolumn{2}{|c|}{ Kapua } & \multicolumn{2}{c|}{ Katilu } & \multicolumn{2}{c|}{ Namoruputh } \\
\hline $\begin{array}{c}\text { Women } \\
(\%)\end{array}$ & $\begin{array}{c}\text { Men } \\
(\%)\end{array}$ & $\begin{array}{c}\text { Women } \\
(\%)\end{array}$ & $\begin{array}{c}\text { Men } \\
(\%)\end{array}$ & $\begin{array}{c}\text { Women } \\
(\%)\end{array}$ & $\begin{array}{c}\text { Men } \\
(\%)\end{array}$ \\
\hline $\begin{array}{l}\text { Selling livestock } \\
\text { products/ Keeping } \\
\text { livestock }\end{array}$ & 3,9 & 21,9 & 17,6 & 30,2 & 36,6 & 48,8 \\
\hline $\begin{array}{l}\text { Farm produce/ } \\
\text { Farming }\end{array}$ & - & - & 37,0 & 42,5 & 1,1 & 12,2 \\
\hline Charcoal burning & 37,6 & 41,1 & 8,1 & 1,9 & - & 2,4 \\
\hline Business & & & 4,4 & 2,8 & 7,5 & 14,6 \\
\hline Weaving baskets & 40,4 & 27,4 & - & - & - & - \\
\hline Casual labourer & - & - & 1,5 & 1,9 & & \\
\hline $\begin{array}{l}\text { Remittance from } \\
\text { family/relative }\end{array}$ & 2,8 & - & 0,7 & - & 1,1 & 2,4 \\
\hline Sale Firewood & 0,3 & - & 13,9 & 4,7 & 20,4 & - \\
\hline Local brewing & - & - & 2,9 & - & 5,4 & 2,4 \\
\hline
\end{tabular}

Source: KVRT Study data collected in 2009

Eriksen and Lind (2005:21) observe that the high prevalence of diversification as a livelihood strategy signals efforts by the Turkana to actively manage vulnerability by increasing the reliability of livelihood assets. But the people's involvement in so many coping and survival strategies is also a sign of distress in Turkana livelihood systems. There is a risk of misinterpreting diversification and market activity for a thriving local economy and robust community and household livelihoods. For example, high levels of livestock sales is an indicator of distress.

\section{Mobility as a Coping and Adaptation Strategy}

There is a strong link between mobility and climate change-induced conflict. Mobility is a carefully managed process by pastoralists, and relies on large social 


\section{Nancy A. Omolo}

networks and the rapid gathering of information on the concentrations of high quality pasture (IIED and SOS Sahel UK 2010:16). Livestock mobility enables pastoralists to take advantage of the ever-changing diversity of dryland ecology. They track the random concentrations of nutrients in space and time. The result of this strategy, when unhindered, is that their livestock are able to feed on a diet that is substantially richer than the average nutritional value of the range they live on (IIED and SOS Sahel UK 2010:15). IIED and SOS Sahel UK (2010:74) argue that pastoralists who are mobile are in a better position to quickly and successfully adapt to a changing climate than those tied to sedentary land uses.

Self-imposed restrictions on mobility due to climate change-induced conflict can have very negative implications for the viability of herds. McCabe (1990:90), for example, estimated that up to one quarter of the territory of the Nginsonyoka, comprising Turkana's best highland grazing areas, was rarely used for fear of livestock raiding. Restrictions on mobility leads to the immediate problem of overgrazing which in the longer term, can lead to serious soil degradation.

The above literature on mobility is in line with KVRT's preliminary findings (KVRT 2009) that reveals that there is rapid change in the Turkana's nomadic lifestyles from nomadism to semi-permanent settlement whereby only part of the family moves in search of pasture and water. There is variation in mobility in the three study sites. Almost all the households stayed permanently in Katilu $(97,7 \%)$ and Kapua $(92,2 \%)$, but less than half in Namoruputh (45\%). The number of households who did not stay in the same place permanently (and are therefore nomadic) is lowest in Katilu (2,3\%) and Kapua (7,8\%) and highest in Namoruputh (54,8\%). More research is needed to know why mobility is high in Namoruputh and low in Kapua given that both are pure/primary pastoralist areas.

However, pastoralists face many challenges due to their mobility as a coping and adaptation strategy to climate variability and change. According to IIED and SOS Sahel UK (2010:37), instead of being mobile and productive, 


\section{Gender and climate change-induced conflict in pastoral communities}

pastoralists are increasingly constrained. Farms frequently block access to their grazing areas, national border controls hinder their trade patterns, and the areas they traditionally preserve for times of drought are now national parks or agricultural schemes. In other areas national government policies actively encourage pastoralists to settle and be 'modern'. These policies are often driven by unfounded perceptions that pastoralism is economically inefficient and environmentally destructive. But this is not evidence based.

Reuveny (2007:658) argues that climate change-induced mobility/migration can promote conflict in the receiving areas, and that the intensity of such conflict may vary across cases. This is due to competition over resources, ethnic tensions, distrust and fault lines (for example, migrant pastoralists and resident farmers may compete over land) (Reuveny 2007:659). Therefore, there is sufficient evidence that climate variability and change lead to conflicts. When pastoralists lose their livelihoods, through loss of access to pastures and water due to climate variability and change, destitution threatens and they turn to violence. This is exacerbated by other factors, including the proliferation of small arms, breakdown in customary control and the absence of State governance in remote border areas (IIED and SOS Sahel UK 2010:76). Whether pastoralists will successfully adapt to the current climate variability and change will depend on how the environmental challenges are tackled and whether mobility is secured.

\section{Gender issues in Turkana}

The above discussions clearly show that climate variability and change have impacts on both women and men, and that there is gender variation in gender coping and adaptation strategies. However, gender coping and adaptation strategies have been weakened by increased climate change-induced conflicts. Barrow and Mogaka (2007:14) state that the situation of women and men in pastoral communities is not static, as incidences of drought have led to transformation in the socio-cultural and socio-economic organisation of pastoral societies. Due to the loss of cattle and other livestock, women play an active role to ensure family survival through engagement in diversified 


\section{Nancy A. Omolo}

income generating activities (Table 1). At the same time, there has been an increase in the number of female-headed households in the ASALs.

Women are particularly vulnerable to insecurity and conflict. This is because women are responsible for their children and cannot flee during periods of raiding. According to Eriksen and Lind (2005:15), raiding and killing have led to several women losing their husbands. Women-headed households are particularly vulnerable because women have poor customary rights to land, wells and livestock. A woman, once married, belongs to the husband's clan, but in some cases finds that the clan is less forthcoming with assistance when her husband has died. Additionally, according to Hendrickson et al. (1998:195), women and children are the first to leave the pastoral sector in times of crisis. They are sent to stay with distant relatives or, ever more, to urban areas where their vulnerability to food insecurity may not be relieved. In some cases, women who have moved to urban areas have been forced to turn to prostitution to survive. Herders dispossessed of livestock are themselves often forced out of the pastoral sector into relief camps or into a search for wage labour. These gradual changes threaten the hopes of recovery as the crucial social ties needed to resume herding are often irrevocably severed.

According to the KVRT study's preliminary findings (KVRT 2009), there is an increase in women-headed households due to the death of a husband, separation/divorce and mothers who remain 'single' (since most men cannot afford bridewealth today due to loss of animals to drought or floods). According to KVRT's findings, female-headed households were at $25 \%$ compared with male-headed households (73,8\%). A few (0,5\%) were child-headed households. The $25 \%$ of female-headed households is quite a substantial number considering that Turkana traditionally is a patriarchal society where most household heads were male. Nevertheless, KVRT findings (KVRT 2009) on decision making in Table 2 indicate that despite the increase in the number of female-headed households, their participation in decision making at the individual level in the household is still low in relation to 


\section{Gender and climate change-induced conflict in pastoral communities}

the following issues: resource use and allocation, investment, and planning about where to move or settle as a way of coping with droughts and floods. This is because decisions are made by husbands/men or community elders (mostly composed of men). However, the level of consultation on decisionmaking issues by both women and men at the household level is higher. There is need for more in-depth studies to examine what consultation means and entails in Turkana.

Table 2: Who makes decisions at the household level

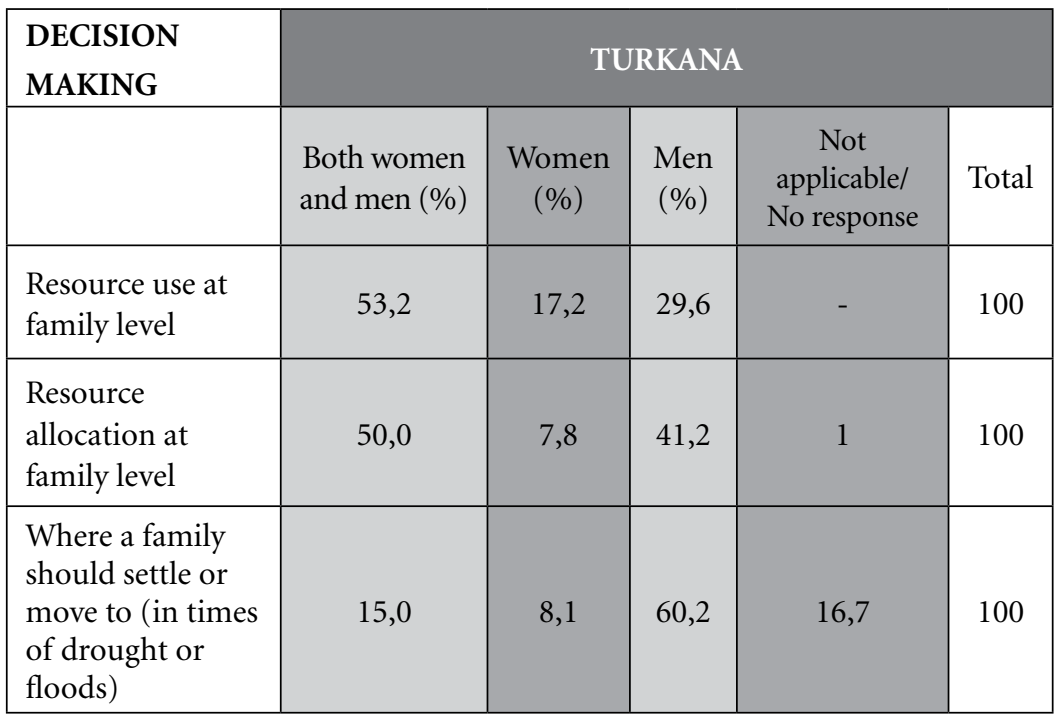

In addition, the KVRT (2009) study also indicates that women in femaleheaded households are more vulnerable to poverty than women who are married. This is because most women in female-headed households cannot own livestock if they do not have a son or cannot afford to employ a herder. Brody et al. (2008:2) state that gender sensitivity in consultation and decision making is essential for effective mitigation and adaptation responses to climate change. There is a need to recognise the capacity of women and men as well as girls and boys to contribute important knowledge and insights. Yet 


\section{Nancy A. Omolo}

women are more likely than men to be absent from decision making, whether in the household or at community, national or international levels. This is either because their contribution is not valued or because they do not have the time, confidence or resources to contribute.

\section{The future of pastoralism and changing climate}

Due to increased climate change-induced conflicts and gender vulnerability, it is important to know the future of pastoralism in order to be able to advise policy-makers on how to strengthen mitigation capabilities and at the same time enhance the adaptive capacity of pastoralists in Turkana. Some analysts argue that the Sahel will continue to dry out as East Africa becomes wetter (Christensen et al. 2007:850). Moreover, climate analyses suggest that there will be highly differential impacts of climate change in East Africa towards the middle of the twenty-first century. Parts of East Africa are expected to become drier, with considerable reduction in the length of the growing season. Other areas, including southern Kenya and northern Tanzania, may become wetter, with increases in the length of the growing season (Thornton et al. 2002, cited in Galvin et al. 2004:1). The projected changes are likely to affect human land use and livelihoods, making these populations more vulnerable.

Figure 2 shows the actual and projected rainfall patterns in Turkana from 1960 to 2040. The figure shows that there have been variations in the rainfall pattern from 1960 to 2009, with seasons of high rainfall to dry seasons without rainfall. Several droughts experienced in Turkana have led to food insecurity, migration and conflicts. Increased rainfall has led to flash floods which have resulted in loss of property, destruction of the infrastructure and diseases. Predictions about the future, according to Figure 2, do not seem positive as the variation in rainfall patterns is expected to continue with wider gaps in rainfall patterns indicating that more droughts and floods will be experienced. 
Figure 2: Projected temporal March, April and May (MAM) rainfall season over Turkana as represented by Lodwar (district headquarters for Turkana)

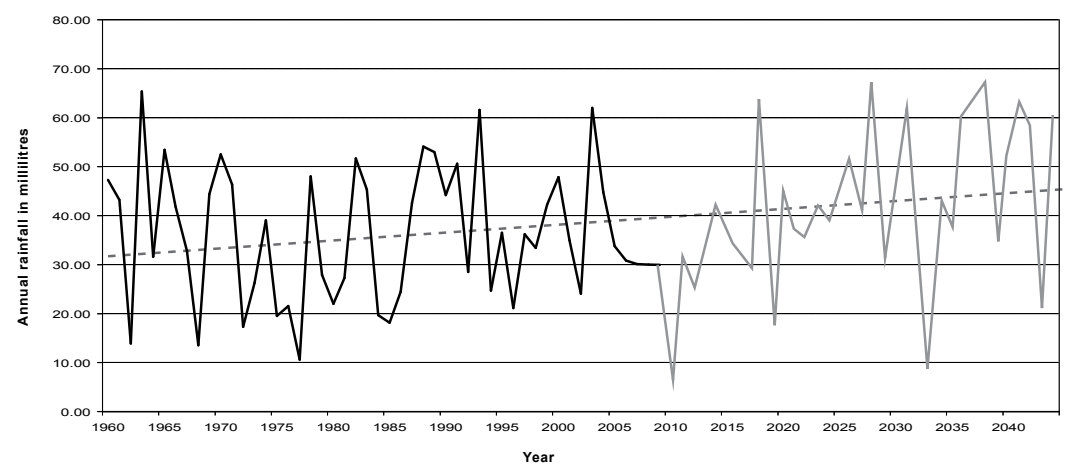

Source: KVRT study, scenarios were developed in 2009

The future of pastoralism remains uncertain. Drought affected areas are estimated to double by the end of the century (from 25\% to 50\%) and drought periods will likely last longer (Birch and Grahn 2007:1). Impacts are already being reported. In Kenya, the short rains which occurred during the months of October to December were extremely enhanced during the 1997/1998 El Niño-Southern Oscillation (ENSO) episode. This episode was followed by the 1999/2000 drought which has been described as one of the worst drought experiences in Kenya's history by the World Food Programme (WFP 2000, cited in Mworia and Kinyamario 2008:011). According to Oba (1992:1), Kenya also experienced drought in the following years (1960/1961, $1969,1973 / 1974,1979,1980 / 1981$ and 1983/1984). The outcome of droughts can be devastating for traditional economies, especially if coping strategies are disrupted - particularly by predatory raids on livestock and disruption of land use patterns. Whenever these extreme climatic conditions like drought and floods occur, they impact negatively on pastoralists' livelihoods through loss of human and livestock lives, starvation and destruction of property. Pastoralists' existing coping and adaptation strategies cannot deal with the current frequent and prolonged changes in climate. 


\section{Nancy A. Omolo}

\section{Conclusion}

Climate change is likely to provoke the drivers of conflict in many livelihood systems, including pastoral production. Climate variability and change have led to increased droughts and floods which have resulted in the loss of animal and human lives, displacements and destruction of property, reduced pasture availability and scarcity of water. This has increased poverty and competition over scarce resources - leading to conflicts, particularly livestock raiding. The way livestock raiding has been transformed from a cultural practice into a predatory/commercial activity with criminal motives and involving the use of automated weapons has caused insecurity in Turkana and hindered pastoralists' mobility - potentially resulting in environmental degradation through soil erosion. In order to cope with these changes pastoralists are diversifying their livelihoods. Nevertheless, livelihood diversification by pastoralists has not resulted in sustainable livelihoods, because it is being done out of desperation or distress. Whether pastoralists will successfully adapt to the current climate change will depend on how the environmental challenges are tackled and whether mobility is secured.

Gender issues in Turkana revolve around women and men's coping strategies to climate variability and change. The impact of climate change-induced conflict has led to an increase in female-headed households due to loss of husbands in conflict. This has increased women's vulnerability because they have poor customary rights in accessing resources.

The future of pastoralism in the context of changing climate remains uncertain. The Turkana rainfall pattern projections for the future do not look positive, as the variations of rainfall patterns will continue with wider gaps in periods of high rainfall and periods of low or no rainfall, implying that there may be more prolonged droughts and increases in floods.

Recognising how conflicts have changed in the modern era offers an important window for examining how herders' livelihoods are being undermined today. In addition, a comprehensive drought contingency plan should be developed 


\section{Gender and climate change-induced conflict in pastoral communities}

to reduce vulnerability in the drylands, particularly among the pastoralists. The plan would coordinate the use of natural resources among all potential users and minimise the conflicts that have become so frequent and destructive between pastoralists within Kenya and across the borders of neighbouring countries. Moreover, there should also be a drought-coordinating agency to ensure consistency, communication, coordination and responsibility within government and between other agencies, thus reducing the number of inappropriate and uncoordinated initiatives.

There is a need to mainstream gender climate change policies because women and men have different roles in the community and because climateinduced conflict impacts on women and men differently. New types of livestock insurance should be developed and promoted to allow pastoralists to cope with droughts and floods. It is important that credit facilities are made accessible to poor households (with gender considerations) to enable them to restock after drought occurrences and also to support the diversified livelihoods which are already taking shape. This should be combined with capacity building of pastoralists in relation to diversified livelihoods initiatives.

\section{Sources}

Ashton, P.J. 2002. Avoiding conflicts over Africa's water resources. Ambio, 31, pp. 236-242.

Barnett, J. and W.N. Adger 2007. Climate change, human security and violent conflict. Political Geography, 26, pp. 639-655.

Barrow, E. and H. Mogaka 2007. Kenya's drylands - Wastelands or an undervalued national economic resource. The World Conservation Union (or International Union for Conservation of Nature, IUCN). Available from: <http://liveassets.iucn.getunik.net/ downloads/kenya_dryland_value_2007.pdf $>$.

Birch, I. and R. Grahn 2007. Pastoralism - Managing multiple stressors and the threat of climate variability and change. In: United Nations Development Programme. Human Development Report 2007/2008: Fighting Climate Change: Human Solidarity in a Divided World. Human Development Report Office, Occasional Paper 2007/45.

Boko, M., I. Niang, A. Nyong, C. Vogel, A. Githeko, M. Medany, B. Osman-Elasha, B. Tabo and P. Yanda 2007. Africa. In: Parry, M.L., O.F. Canziani, J.P. Palutikof, P.J. van der Linden and C.E. Hanson eds. Climate change 2007: Impacts, adaptation and vulnerability. Contribution of Working Group II to the Fourth Assessment Report of the Intergovernmental Panel on 


\section{Nancy A. Omolo}

Climate Change. Cambridge, Cambridge University Press. Available from: < http://www. ipcc.ch/pdf/assessment-report/ar4/wg2/ar4-wg2-chapter9.pdf>.

Brody, A., J. Demetriades and E. Esplen 2008. Gender and climate change: Mapping the linkages - A scoping study on knowledge and gaps. Institute of Development Studies (IDS) report to the UK Department for International Development (DFID). Available from: <www. unep.org/.../climate_change/.../Gender-and-climatechange/DFID_Gender_Climate_ Change.pdf $>$.

Christensen, J.H., B. Hewitson, A. Busuioc, A. Chen, X. Gao, I. Held, R. Jones, R.K. Kolli, W.T. Kwon, R. Laprise, V. Magaña Rueda, L. Mearns, C.G. Menéndez, J. Räisänen, A. Rinke, A. Sarr and P. Whetton 2007. Regional climate projections. In: Solomon et al. 2007, pp. 849-926.

Cullis, A. and A. Pacey 1992. A development dialogue: Rainwater harvesting Turkana. London, Intermediate Technology.

Daily Nation 2009a. East Africa drought in fifth year, millions hungry. Daily Nation supplement, Tuesday, 29 September 2009. Nation Media group, Nairobi, Kenya.

Daily Nation 2009b. Never ending war between Turkana and Sudanese. Daily Nation supplement; Wednesday, 21 October 2006. Nation Media group, Nairobi, Kenya.

Dankelman, I., K. Alam, A. Khurshid, W.B. Ahmed, Y.D. Gueye, N. Fatema and R.M. Kutin 2008. Gender, climate change and human security: Lessons from Bangladesh, Ghana and Senegal. Report prepared for Hellenic Foundation for European and Foreign Policy (ELIAMEP) by the Women's Environment and Development Organization (WEDO), ABANTU for Development in Ghana, Action Aid Bangladesh, and ENDA in Senegal. Available from: $<$ www.gdnonline.org/.../WEDO_Gender_CC_Human_Security.pdf $>$.

Denton, F. 2001. Climate change, gender and poverty - Academic babble or realpolitik? Point de Vue, 14, pp. 1-2.

Fiki, O.C. and B. Lee 2004. Conflict generation, conflict management and self-organising capabilities in drought-prone rural communities in north eastern Nigeria: A case study. Journal of Social Development in Africa, 19, pp. 25-48.

Eriksen, S. and J. Lind 2005. The impacts of conflict on household vulnerability to climate stress: Evidence from Turkana and Kitui Districts in Kenya. Human Security and Climate Change, An International Workshop, Holmen Fjord Hotel, Asker, near Oslo, 21-23 June 2005. Available from: <wikiadapt.org/.../The_impacts_of_conflict_on_household_ vulnerability_to_climate_stress.pdf $>$.

Galvin, K.A., P.K. Thornton, R.B. Boone and J. Sunderland 2004. Climate variability and impacts on east African livestock herders: The Maasai of Ngorongoro Conservation Area, Tanzania. African Journal of Range and Forage Science, 21 (3), pp. 1-2.

GoK 2002. Turkana District Development Plan 2002-2008. Ministry of Planning and National Development. Nairobi, Government Printer. 


\section{Gender and climate change-induced conflict in pastoral communities}

GoK 2005a. Constituency report on well-being in Kenya. Based on the Kenya Integrated Household Budget Survey 2005/2006. Kenya National Bureau of Statistics. Nairobi, Government Printer.

GoK 2005b. Sessional paper on sustainable development of arid and semi-arid lands of Kenya. Ministry of Planning and National Development. Nairobi, Government Printer.

GoK 2008. Turkana Central District Development Plan 2008-2012. Ministry of State for Planning, National Development and Vision 2030. Nairobi, Government Printer.

Hegerl, G.C., F.W. Zwiers, P. Braconnot, N.P. Gillett, Y. Luo, J.A. Marengo Orsini, N. Nicholls, J.E. Penner and P.A. Stott 2007. Understanding and attributing climate change. In: Solomon et al. 2007, pp.665-744.

Hendrickson, D., J. Armon and R. Mearns 1998. Vulnerability: The case of livestock raiding in Turkana District, Kenya. Disasters, 22 (3), pp. 186-195.

IIED (International Institute for Environment and Development) and SOS Sahel International UK 2010. Modern and mobile: The future of livestock production in Africa's drylands. Available from: <www.iied.org/pubs/pdfs/12565IIED.pdf >

Kirbride, M. and R. Grahn 2008. Survival for the fittest: Pastoralism and climate change in East Africa, Oxfam International, Briefing Paper August 2008. Available from: <http://www. ciaonet.org/pbei/oxfam/0003433/f_0003433_2544.pdf>.

KVRT (Kenya Vulnerability Research Team) 2009. Enhancing adaptive capacity of pastoralists to climate change induced vulnerability in northern Kenya. Preliminary findings of a study findings, undertaken between January 2008 and December 2009. Turkana, Kenya.

Le Treut, H., R. Somerville, U. Cubasch, Y. Ding, C. Mauritzen, A. Mokssit, T. Peterson and M. Prather 2007. Historical overview of climate change. In Solomon et al. 2007, pp. 94-122.

McCabe, J.T. 1990. A case against the tragedy of the commons. Human Ecology, 18 (1), pp. 81-103.

Mworia, J.K. and J.I. Kinyamario 2008. Traditional strategies used by pastoralists to cope with La Nina induced drought in Kajiado, Kenya. Africa Journal of Environmental Science and Technology, 2 (1). Available from: <http:www.academic journals.org/Ajest $>$.

Oba, G. 1992. Ecological factors in land use conflicts: Land administration and food insecurity in Turkana, Kenya. Available from: <http://www.odi.org.uk/work/projects/pdn/ papers/33a.pdf>.

Orindi, V.A., A. Nyong and M. Herrero 2007. Pastoral livelihood adaptation to drought and institutional interventions in Kenya. In: United Nations Development Programme. Human Development Report 2007-2008: Fighting Climate Change: Human Solidarity in a Divided World. Human Development Report Office, Occasional Paper 2007/54.

Reuveny, R. 2007. Climate change-induced migration and violent conflict. Political Geography, 26, pp. 656-673

Solomon, S., D. Qin, M. Manning, Z. Chen, M. Marquis, K.B. Averyt, M. Tignor and H.L. Miller eds. 2007. Climate change 2007: The Physical Science basis. Contribution of Working 


\section{Nancy A. Omolo}

Group I to the Fourth Assessment Report of the Intergovernmental Panel on Climate Change. Cambridge, Cambridge University Press.

Thomas, D.S.G. and C. Twyman 2005. Equity and justice in climate change adaptation amongst natural-resource-dependent societies. Global Environment Change, 15, pp. 115-124.

Thornton, P.K., R.L. Kruska, N. Henninger, P.M. Kristjanson, R,S. Reid, F. Atieno, A. Odero and A. Ndegwa 2002. Mapping poverty and livestock in the developing world. International Livestock Research Institute, Nairobi, Kenya.

Watson, C. 2003. Pastoral women as peacemakers. Community-based Animal Health and Participatory Epidemiology Unit (CAPE) of the African Union's Interafrican Bureau for Animal Resources (AU/IBAR), Nairobi, Kenya. Available from: <www.eldis.org/fulltext/ PastoralWomenAsPeacemakersApril2003.pdf $>$

Welfare Monitoring Survey II 1994. Basic Report. Central Bureau of Statistics. Nairobi, Government Printer.

WFP (World Food Programme) 2000. Kenya's drought: No sign of any let up. WFP, Rome, Italy. Available from: <www.wfp.org/newsroom/in_depth/Kenya.html> 